\title{
On the Awakening of Female Consciousness from the Opium War to the Great Revolution Period
}

\author{
Tingting Pan, Xiancheng He \\ School of Political Science and Law, Sichuan University of Arts and Science, Dazhou, China \\ Email: xlightwhite@163.com
}

How to cite this paper: Pan, T.T. and He, X.C. (2020) On the Awakening of Female Consciousness from the Opium War to the Great Revolution Period. Open Access Library Journal, 7: e6494.

https://doi.org/10.4236/oalib.1106494

Received: June 2, 2020

Accepted: June 15, 2020

Published: June 18, 2020

Copyright () 2020 by author(s) and Open Access Library Inc.

This work is licensed under the Creative Commons Attribution International License (CC BY 4.0).

http://creativecommons.org/licenses/by/4.0/

\section{(c) (i) Open Access}

\begin{abstract}
In the long period of feudal society, women were always bound by various feudal ethics, "the three obediences and the four virtues", "husband guides wife" required their words and actions. Under the feudal system, women not only did not have the right of education, but also did not have the right of freedom and equality, regarded as male subservience. After the outbreak of the Opium War, the idea of bourgeois democracy emerged in China. In order to find ways to save the country and its people, the bourgeois intellectuals set off a wave of reform. During this period, women's consciousness of autonomy, emotion, revolution and value was constantly awakening.
\end{abstract}

\section{Subject Areas}

Sociology

\section{Keywords}

The Opium War, the Great Revolution Period, Female Consciousness, Awakening

\section{Introduction}

With the rolling wheels of the Times and the outbreak of the opium war, China was gradually reduced to a semi-colonial and semi-feudal society. With the modernization of Chinese society, the issue of women as one of the main social issues has become more and more prominent. With the gradual deepening of western learning, many progressive people and thinkers began to think and discuss this problem. Some intellectual women began to question the social status and status of traditional women, began to pursue freedom, equality and independence, and 
challenged the traditional Chinese political system and feudal ethics. As an independent person, women's consciousness began to awaken, not passively waiting for their own liberation, actively looking for their own liberation, which is unprecedented doubt and challenge to the awareness and teaching of "the three obediences and the four virtues", "principle of feudal moral conduct", "lack of talent in a woman is a virtue", as well as male superiority and female inferiority. This paper attempts to analyze the awakening of female consciousness from the change of women's own thoughts and actions.

\section{Pessimism about Marriage and Denying of the Bold Pursuit of Love and Freedom-The Awakening of Emotional Consciousness}

In human society, women's psychological quality, their natural position in the human group and the role of various social factors make women pay more attention to the feelings of love than men. Therefore, love in a sense becomes a basic starting point for them to look at themselves and the society. Their pursuit of their own value is firstly carried out in the field of "love". They regard the free choice of love as one of the most important contents of women's own value. The freedom of love and marriage is most directly related to the future destiny of women, and more specifically reflects the degree of women and social awakening.

After thousands of years of indoctrination and suppression of moral and ethical values in feudal society, women's emotional consciousness was gradually silenced by the heavy shackles, and they became the victims of feudal commercial marriage and arranged marriage. The loss of emotional consciousness leads to a dull and old-fashioned way of life, like responsibility, and the attitude that life is supposed to be. For them, the meaning of life is not a kind of joyful enjoyment, not a kind of happy experience, not a kind of pursuit of life, but a heavy burden, or even an inescapable torture. If women want to emancipate themselves from the spirit and work hard for themselves, they should start from pursuing the marriage of love and ending the marriage without love. This is the most basic demand for women's rights and it is an announcement to restore women's emotional consciousness, make it clear and know the declaration of self-dignity.

With the outbreak of the Opium War, the gradual spread and deepening of western learning, and the introduction of the concept of freedom and equality of the western bourgeoisie, many progressive thinkers began to vigorously advocate the freedom of marriage and condemned the harm of arranged marriage to women. In Doctrine of Benevolence, Sitong Tan criticized the feudal ethics of "father guides son" and "husband guides wife". Exposing the harm of arranged marriage to young men and women, as well as the profound difficulties caused to women by the feudal concept of chastity. At this point, a group of women began to realize the importance and necessity of independent marriage. Without this freedom, there would be no personal independence. Women are completely in a position of passive obedience because of arranged marriage. Therefore, only by breaking 
away from arranged marriage can they gain independence, choose their own life and pursue love according to their own ideas. In July 1898, the women's journal, founded by the women of the reform movement, criticized arranged marriages in feudalism, nakedly uncovering the feudal ethical code under which women were oppressed and exploited, unable to make their own decisions in the marriage struggle hopeless situation. During this period, a few women boldly proposed that on the issue of marriage, "everything can be independent, that is, the rights of parents cannot be suppressed". They strongly demanded the elimination of the "the three obediences and the four virtues" and the "husband guides wife" [1], demanding the change of women's real life conditions and the realization of equality of rights and freedom of marriage. For example, Jin Qiu, a bourgeois female revolutionary who suffered from the feudal arranged marriage, broke away from the feudal marriage and stepped out of her family. Such cases are too numerous to enumerate. For example, Chen Qifen, Liang Qichuan, Xu Mulan and Zhuang Hanqi also broke away from the feudal family one after another and became a rebel of feudal ethics [1]. At that time, there were many women who were fighting, and despite the huge resistance, they did not give up or give in. Although during this period, the people who could change their ideas and renew their people were mostly progressive students and educated women of the more enlightened bourgeoisie and petty bourgeoisie, the proportion of whom is not large, and the scale and scope are not too wide, but these women have awakened the emotional awareness of freedom of love and freedom of marriage.

\section{The Exploration of Women's Independent Personality- The Awakening of Independent Consciousness}

Under the feudal system, women were oppressed and exploited like mountains. After the Opium War broke out and the modernization process began, the nature of women's long-term oppression was changed and they began to pursue independently. But for a long time, the traditional concept of feudal society shackles people's sense of autonomy. In the early days of the Taiping Heavenly Kingdom, with the awakening of women's self-consciousness, this self-consciousness of women was formed for a short time and then suppressed. Hong xiuquan's worship of god absorbed the Christian spirit of equality, which told women that they were equal and independent people, thus causing the awakening of consciousness. Although the consciousness is weak, but for a long time, for the women deeply immersed in principle of feudal moral conduct and the view that men are superior to women, the germination of this consciousness itself is feudal morality. Many women actively responded to the call of "the Taiping Heavenly Kingdom" and took part in the uprising. Just like men, some women held official positions such as "women's camp" specially set up in the Taiping Heavenly Kingdom. Since then, the number of "women's camps" has grown to more than 100,000, with female managers playing a prominent role. The expansion of women's organizations and women's public responsibilities is a great encouragement to wom- 
en as they begin to reassess their values and pursue their status. In the end, the Taiping Heavenly Kingdom could not support itself because of its own limitations on women, but as a large-scale social group, women could actively participate in social activities. This breakthrough is a kind of rebellion against the traditional Chinese feudal moral discipline, which, to some extent, promoted the awakening of women's sense of autonomy. However, "the Taiping Heavenly Kingdom" finally returned to the old feudal way of principle of feudal moral conduct, resulting in a variety of oppression and norms for women. In the later stages, the "women's camp" was also known as the "women's venue". In the later stages of the campaign, the men's and women's venues did not allow couples to reunite. Women are not only in combat but also in logistics, and are subjected to forced and exhausting labor.

The real awakening of modern women's independent consciousness should start from the Opium War and the eastward transmission of western sciences, especially from Hundred' Reform. With the development of modernization, more and more western culture has penetrated into China. In the western learning process, China's modern society is separated from traditional culture and moves towards western civilization. The tendency to learn from the west in modern society has gradually had a great impact on women's perception. Since the Opium War, the society has faced grave crisis. With the pace of modernization, the society has entered an era of transformation. In Women and Modern Chinese Society, it is also revealed that the autonomy of Chinese modern female consciousness was awakened in the conflict between traditional culture and western culture through communication collision and fusion in a specific social and historical environment. "In China's feudal society for thousands of years, Chinese women were bound by the four ropes of feudal power, clan power, divine power and marital power. This is a shackle and a doctrine of enslavement to women. To liberate themselves, women must break these shackles completely." [2]. They began to break out of their families, out of the social definition of the world, worried about the rise and fall of the country and the unknown future. They are eager to break free from the shackles of the old society of procreation and family security, enter the society, and perform their duties to save the country from danger. The struggle for women's rights and women's liberation is an important signal to awaken women's independent consciousness in this period.

\section{A Declaration of the Spirit of Resistance-The Awakening of Revolutionary Consciousness}

In the process of modernization, the invasion of foreign powers, the humiliation of the treaty, the grave national crisis, tens of thousands of people are in the fire and water and countless people rushed to save the country on the road to save life, to explore, to try, to find a way to really save the country. There is "Menare responsible for their country's rise or fall", and "women are responsible for their country's rise or fall". 
It was not until the great revolution that women realized that "the Chinese women's movement, which had taken the characteristics of the national revolutionary movement and was under the dual oppression of the foreign imperialists and the northern warlords, could not have a basis for the existence of women's rights unless human rights and civil rights were first won back to China." [3]. They realized that saving the country and the people is not only the responsibility of men, but also the responsibility of every Chinese. Before the national crisis, they also showed their revolutionary views and political attitudes. Only by consciously devoting themselves to the cause of revolution can they make further progress on the road of striving for equality and freedom.

After the founding of the party, the ministry of women was formally established in 1922, and women's work became the focus of attention. The liberation of women is regarded by the party as an important part of the liberation of the proletariat. The liberation of women will also strengthen the party's revolutionary ranks and forces. With this guiding ideology, the party attaches great importance to and pays particular attention to women's work, especially when they join the party. Some women use party membership as a way to signal their determination, revolutionary values and political attitudes. At that time, under the domestic revolutionary situation, women joined the party actively, and many women kept their party membership secret. With the evolution of the revolutionary situation and the development of the revolution, the proportion of women party members in the party gradually increased. The Shanghai party organization, for example, in the second half of 1924, there were 109 CPC members in Shanghai, among whom 7 were women, accounting for $6.4 \%$ of the total. After the May 4th movement, the number of CPC members in Shanghai increased to 1,080, among whom 186 were women, accounting for 17.2\%.By April 1926, there were 1,809 party members in Shanghai, of whom 383 were women, accounting for $21.2 \%$. It can be seen from this that in the industrial city of Shanghai, the proportion of female party members is gradually increasing [4].

It is of great symbolic significance for women to take part in the revolution and join the party. Their thoughts have the identity of social liberation and individual liberation. As a group that has been exploited and oppressed for a long time, restricted by ideas, education and surrounding conditions, revolution is unfamiliar and distanced, even fearful, to women under the discipline. With the spread of new ideas, women's liberation has been valued by young women with revolutionary ideas. They constantly exposed the ignorance and unequal treatment of women in the society at that time, oppressed and exploited without dignity and freedom, and inspired women to rise up in revolution. By integrating themselves into the revolutionary struggle, the women armed themselves with ideas, defined their political attitudes, and raised their national sentiments to demand a better and more dignified existence. In many places they were more determined than men. For them, they should not only participate in the current of the great revolution, go to the difficult times together and fight against the emperor and the warlord, but also, as the first awakening among women, they are the pioneers 
and pioneers of women's liberation. Therefore, their choice has both the sense of responsibility of revolution, the responsibility of the nation, and the important mission of women's liberation. This identity is closely connected with the times. In the revolutionary sense, the awakening of women group has the dual value of national liberation and self-liberation. For this reason, the awakening of women's revolutionary consciousness symbolically represents the awakening of the nation to some extent, and also indicates the self-salvation of women as a vulnerable group.

\section{Seek Equal Status with Men-The Awakening of Value Consciousness}

Fourier wrote that the social progress and changes of a certain era were commensurate with the degree to which women moved towards freedom [5]. With the penetration of western culture, the main manifestation of the awakening female consciousness from the society is that they want to receive school education. This is one of the most prominent aspects of the awakening of female consciousness here.

Under traditional feudal rule, women were not eligible for school education. In 1844, Mr. Elgie, a British missionary, founded the first high school for girls in ningbo, which was also the beginning of high school education for girls in China, and more and more people came to study there. Shi $\mathrm{Hu}$ also pointed out the social deformity of lack of education for women and the importance of liberation education for women. Liberation education, whether in high school or in the common education school, is ready for the ordinary life. In 1912, in the early years of the republic of China, the ministry of education promulgated the rules in the Implementation of Junior High School: "The subjects of the secondary school are moral cultivation, Chinese, foreign languages, history, geography, mathematics, natural history, physics, chemistry, legal economy, painting, handwork, music and gymnastics. Girls' high school plus housework, gardening, sewing... Moral cultivation should aim at cultivating moral thought and sentiment, and encourage the practice of practice, complete with the character of the people, moral cultivation should be given to the moral essentials, and gradually to the country's social family responsibility, and teach ethics, especially should pay attention to the characteristics of the country's moral." [6]. From then on, the educational purpose of women was no longer to learn the three obediences and the four virtues and (the view that) men are superior to women in Women Rings of the feudal society, and how to take care of their husbands, raise their children and support their families, but to master scientific and technological knowledge through education to achieve a better life and equality between men and women. In 1923, members of the female star society set up Tianjin No.1 continuation school with the purpose of "providing relief for women out of school, giving them considerable knowledge and advanced skills so that they could earn a living on their own", "bringing about a great new trend of thought in the field of women in Tianjin", so as to achieve "the purpose of assisting oppressed women" [7]. At the same 
time, the school also carries out ideological education for the students, disseminating patriotic thoughts, liberating thoughts and bourgeois thoughts of freedom and equality, which, to some extent, promotes the awakening of female consciousness, the equal liberation and the realization of independence are the educational core of intellectual women themselves. Not only that, in order to enable more women to broaden their horizons, improve their self-confidence, and inspire women's sense of self-reliance, advanced intellectuals have actively founded more than 30 kinds of women's newspapers, like Female Newspaper, Journal of Women, Chinese Female Newspaper, Women's World, China Women's Magazine and so on to educate the vast number of women, broaden their horizons, enhance self-confidence and awaken women's sense of self-reliance with remarkable results. This struggle, reflected not only in the establishment of girls' schools, but also in the proportion of female students studying abroad, the administrators who run girls' schools and the women's newspapers, was the result of women's pursuit of equality and independence during this period. At the same time, the desire to participate in politics is also an important signal of awakening of value consciousness. Under the feudal society, women had no say in politics, but now they want to participate in politics. Men can participate in politics and women can also participate. Women's political and law schools were founded with the aim of accumulating women's political knowledge and improving their abilities so that elections could be held. Hanying Zhang initiated and organized the "women's league for political participation", calling on women to actively study and take action. As the capital for political participation and discussion, "they cannot get what they want, but they cannot have it when they get it" [1].

In addition to the "women's league in politics and politics", there are also the common love association, Young Women's Christian Association, the women's association of China and so on. Women bravely broke away from the shackles of feudal etiquette and law, actively integrated into society, participated in the discussion of politics, gave play to their own strength and light, and shouted, explored, struggled and struggled for the survival of the country and the nation.

Those outstanding women, such as female alliance member known as Jin Qiu, Xiangning He, Zongsu Lin and so on, modern China's first female journalist Yufang Qiu, foreign female talent Ruifang Liu and Shan Shili, one of the earliest women to go abroad, and so on. They are all beacons on the road of women's awakening and demand for liberation, leading and inspiring all people. However, each one who seems to be unknown in the struggle is a firefly, striking under the four walls with his own flesh and blood, and carrying the idea of freedom and equality through a hundred years.

\section{Conclusion}

To sum up, the awakening of women's consciousness in Chinese society from the Opium War to the Great Revolution is a historical inevitability, and it also explores and progresses from emotional consciousness, independent consciousness, revolutionary consciousness, value consciousness and other aspects. Although the 
women who began to awaken at that time were mostly educated female students and educated women of the bourgeoisie and petty bourgeoisie, they were only a small part of the women in the vast land of China. But this small part can already be used as a firefly torch, a beacon for passers-by. The awakening of national consciousness, and the pursuit of equality, freedom, and the exploration of its value for the right to appeal, are starting to become an important signal of female consciousness awakening. It is this kind of significant awakening and exploration that drives more and more women to break through the feudal mountains and shackles and embark on the road of independence. The research of this paper is mainly from the perspective of women themselves to explore their thoughts and behaviors. It is limited to the defined period and does not cover them from the perspective of modern times. There is a long way to go for comprehensive research on this issue. I hope that other scholars can continue to conduct in-depth research and make a comprehensive summary after exchanges and discussions. Research on women's awakening of social consciousness can help us better understand the social and historical development at that time in a more comprehensive way. Women's liberation and development, to some extent, is a measure of social openness and development of the scale. Until today's world, women's rights and liberation is still a hot topic, to which we still need to continue to pay attention to and explore, so as to achieve social stability, harmony, healthy development.

\section{Conflicts of Interest}

The authors declare no conflicts of interest regarding the publication of this paper.

\section{References}

[1] Jiang, B.L. (2003) On the Awakening of Women's Independent Consciousness in the Late Qing Dynasty. Journal of Sichuan College of Education, 3, 33-34.

[2] Li, B.Y. (1997) Characteristics of Women's Liberation Movement during the May Fourth Movement. Journal of Hubei University (Social Science Edition), 3, 100.

[3] Xiang, J.Y. (2011) Anthology of Jingyu Xiang. People's Publishing House, Beijing, 296.

[4] Yi, F.L. (2014) The Awakening of Women's Revolutionary Consciousness during the Great Revolution Period. Jiangxi Social Sciences, 2, 138.

[5] Wu, P.C. (2008) From Female Slaves to Women-the Awakening of Female Consciousness of Contemporary Chinese Rural Women in Hu Gu's Novels. Data of Culture and Education, 12, 22.

[6] Xiao, G.G. (2011) A Study on School History Education in the Period of the Republic of China. Master's Degree Thesis, Ningxia University, Yinchuan.

[7] Data Collection Committee on Party History of Tianjin Municipal Committee of the Communist Party of China (1987) Yingchao Deng and the Early Women's Movement in Tianjin. China Women Publishing House, Beijing. 